\title{
Silver birch aboveground biomass allocation pattern, stem and foliage traits with regard to intraspecific crown competition
}

\author{
Bohdan Konôpka ${ }^{1,2 *}$, Jozef Pajtík ${ }^{1}$, Vladimír Šebeň ${ }^{1}$, Katarína Merganičová $^{2,3}$, Peter Surový2 \\ ${ }^{1}$ National Forest Centre, Forest Research Institute Zvolen, T. G. Masaryka 2175/22, SK - 96001 Zvolen, Slovak Republic \\ ${ }^{2}$ Czech University of Life Sciences Prague, Faculty of Forestry and Wood Sciences, Kamýcká 176, CZ - 16521 Praha 6-Suchdol, \\ Czech Republic \\ ${ }^{3}$ Technical University in Zvolen, Faculty of Forestry, T. G. Masaryka 24, SK - 96053 Zvolen, Slovak Republic
}

\begin{abstract}
In the conditions of Central Europe, silver birch (Betula pendula Roth) has so far not been an important species for commercial purposes but might be relevant from ecological point of view. For instance, prompt succession by birch and other pioneer tree species at large-scale post-disturbance areas is necessary to compensate for previous carbon losses by natural disasters. Therefore, our attention was focused on 14-year-old birch trees growing at the wind-thrown area in the High Tatra Mts. (northern Slovakia). We sampled aboveground biomass of 20 silver birch trees representing four classes of crown competition: 0 - competition free crowns, 1 - crowns under mild competition, 2 - crowns under moderate competition, 3 - crowns under severe competition. We studied biomass allocated to stems, branches and foliage, and basic properties of stems and foliage. The crown-competition free birches were nearly $13 \mathrm{~m}$ high, and their aboveground tree biomass was $150 \mathrm{~kg}$. The biomass of birches under severe competition was five times lower. Crown competition modified biomass ratios of foliage to branch as well as of branch to stem. Our results showed that birches under severe competition stress invest more in height than in diameter. At the same time, crown competition modified foliage weight and specific leaf area (SLA), which was clear mostly in the upper part of the crowns. However, foliage area was influenced by crown competition only to a negligible extent. Our main finding is that foliage position (upper, middle or lower third of crown) affected foliage properties more than intraspecific crown competition. Finally, we pointed out that silver birch is a rather productive species that is not ecologically demanding. Therefore, it might be a prospective tree species under the ongoing climate change and the present period of intensification in renewable resources utilisation.
\end{abstract}

Key words: post-disturbance area; Tatra National Park; tree components; crown competition; young stand; specific foliage area

Editor: Miroslav Hájek

\section{Introduction}

Birches (Betula sp.), especially silver birch (Betula pendula Roth) and downy birch (Betula pubescens Ehrh.), are short-lived broadleaved species occurring in most European regions but mainly in Scandinavia and Russia (San-Miguel-Ayanz et al. 2016). In the conditions of Central Europe, either silver birch or downy birch are not important for commercial purposes but are ecologically relevant (Kula 2011). On the other hand, in Scandinavian and Baltic countries birch is an economically relevant species, since its contribution to forest stock is about $16 \%$ in Finland and Norway, 11\% in Sweden, over 20\% in Estonia and Latvia, and $17 \%$ in Lithuania (Hynynnen et al. 2010). In the northern countries birch trees repre- sent commercially the most important source of hardwood and an important part of coniferous plantations, especially Scots pine (Pinus sylvestris L.) and Norway spruce (Picea abies L. Karst; see also Kurvits et al. 2020).

Birches have often been studied with regard to soil amelioration via their foliage litter (e.g. Cotrufo et al. 1995; Schua et al. 2015; Kacálek et al. 2017). Since the species are relatively resistant to emissions, they were frequently planted on sites deteriorated by noxious substances, for instance in Czechia (Kula 2011). Moreover, the species often occupy post-disturbance areas and together with other pioneer species, especially common aspen (Populus tremula L.), goat willow (Salix caprea L.), rowan (Sorbus aucuparia L.) create favourable conditions for other climax tree species (Konôpka et al. 
2019). Birch is much less attractive for game as forage than other pioneer species, and thus, it is rarely damaged by browsing (Findoo \& Petráš 2007). Therefore, in regions exposed to red deer it has a higher survival rate than other pioneer species. Moreover, on post-disturbance or former agricultural lands birch is usually more productive than most other forest tree species (e.g. Zasada et al. 2014; Konôpka et al. 2019).

Martiník et al. (2018) suggested birch as an alternative trees species in the beech vegetation zone of the north-eastern part of the Czech Republic after spruce decline. Valkonen and Valsta (2001) presented an analysis on the economics of the two-storied birch-spruce mixture in Finland. Their results indicated that in Finnish economic and technical conditions it is profitable to grow a birch over-storey in a spruce plantation up to commercial volume. The main aim of growing downy birch is to produce pulp wood and fuel wood with low costs (Hynynen et al. 2010). Wood of pioneer tree species, including birch, grown on disturbed areas might be a source of wood for renewable energy production (Stark et al. 2013). The size or quality of birch stems is often too poor for veneer and saw logs, especially when growing on infertile or wet sites (Hynynen et al. 2010). Moreover, birch can play an important role in carbon sequestration on sites where other tree species can not grow or develop very slowly.

Most papers on birch biomass come mostly from northern parts of Europe, specifically Finland (Lehtonen et al. 2004; Repola 2008), Sweden (Claesson et al. 2001; Johansson 2007), and Estonia (Uri et al. 2007). Recently, a couple of works focused on birch biomass and wood production in Central Europe (e.g. Bronisz et al., 2016; Jagodzinski et al. 2017; Martiník et al. 2018). Their mutual motive has been great growth potential of birch in terms of biomass production. At the same time, the authors pointed out that intentional or spontaneous replacement of herbaceous vegetation on former agricultural land by forest trees, especially birch, can significantly contribute to carbon fixation and conservation. Prompt reforestation of large-scale post-disturbance areas (by both pioneer and climax tree species) is necessary to compensate previous carbon losses by natural disasters (e.g. Seidl et al. 2014; Konôpka et al. 2019).

While a number of papers focused on birch biomass models or estimates, fewer works studied biomass allocation patterns or components traits in terms of ecological conditions or biological aspects (just partly met in papers Uri et al. 2007; Jagodzinski et al. 2017). Our review of Central European literature focusing on birch indicated neglected interest in this genus. In general, understanding the patterns of biomass partitioning of a variety of species is of high importance in the field of tree physiology and plant ecology, and has also applications for forestry management (Mensah et al. 2016). Considering a variety of tree species, many works studied biomass allocation and foliage traits with regard to competition (e.g. Hommel et al. 2016; Zhou et al. 2018; Yang et al. 2019). Some authors (e.g. Shipley 2006; Milla etal.2008) used the ratio between foliage and total dry plant biomass (leaf mass ratio) or between foliage area and total plant dry biomass (leaf area ratio) to describe ecological and production interactions.

The Slovak National Inventory data showed that while birch contributed to growing stock in forest lands only by about $1 \%$, much larger contribution (about $6.5 \%$ ) was estimated for non-forest (prevailingly former agricultural) lands (Šebeň et al. 2017). In Slovakia, the inventory data suggest that birch is more frequent in young stands than in older ones. This is partly caused by large-scale forest calamities that occurred in the last two decades (see for instance Kunca et al. 2019) followed by reforestation with high share of spontaneous natural regeneration of pioneer species. Hence, the contribution of birch to forest standing stock on both forest and former non-forest land might increase in near future due to its biomass accumulation over time and increasing frequency of forest disturbances (Seidl et al. 2014).

Therefore, the main aim of our paper was to quantify the aboveground birch biomass (i.e. dry mass expressed in $\mathrm{kg}$ ) allocated to individual tree components in a young mixed stand growing at a post-disturbance site 14 years after the wind damage. We hypothesised that crown competition stress influences aboveground biomass allocation patterns as well as stem and foliage traits of birch trees.

\section{Material and methods}

Our attention was focused on the High Tatra Mts. (the Tatra National Park) situated in northern Slovakia. The bedrock of the region is predominantly formed by sediments of granodiorites. Forest soils are prevailingly lithic leptosols and podzols. The climate is cold (annual mean temperature is nearly $5.0^{\circ} \mathrm{C}$ ) and moist (annual precipitation total of over $1,000 \mathrm{~mm}$ ), and snow cover lasts between 110 - 130 days (e.g. Vološčuk et al. 1994). The main part of the territory belongs to the post-disturbance area arisen after the large-scale windstorm on $19^{\text {th }}$ November 2004. The wind destroyed spruce-dominated forests with epicentre at elevations between 700 and $1,400 \mathrm{~m}$ a.s.l. The damaged area resembled a continuous belt, which was $3-5 \mathrm{~km}$ wide and nearly $35 \mathrm{~km}$ long (Konôpka et al. 2019). The forest stands inside this belt were nearly completely destroyed (mainly uprooted less stem-broken), except for few forest clusters typical with preponderance of European larch (Larix decidua Mill.) and at a few sites also of Scots pine (Pinus sylvetris L.). The area of the damaged forests covered almost 10,000 ha. The post-disturbance area was managed in three ways regarding the degree of nature protection: from processing all amount of merchantable wood, through partly-processed calamity wood $(30-60 \%$ of 
merchantable wood), up to excluding wood processing with exclusive natural succession. The main part of the calamity wood was processed during three years after the disturbance (2005 - 2007). As for forest regeneration, different approaches were implemented with respect to the degree of nature protection. While natural regeneration was preferred, combined natural and artificial reforestation occurred at many sites, and only very few sites were reforested exclusively by planting.

Our field activities were performed during the second half of the growing season in 2018, i.e. 14 years after the wind disturbance. Aboveground biomass sampling and measurements of birch were done around our permanent research transect "Danielov dom” (Konôpka et al. 2017). The sampling site is located about $450 \mathrm{~m}$ south from the road No. 537 (well-known as "the Road of Freedom") and $2.0 \mathrm{~km}$ southwest from the Tatranská Polianka village. The altitude is between 985 and 990 m a.s.l., southern inclination. The forest stand was composed of silver birch, Norway spruce, European larch, rowan, Scots pine and some other broadleaved species. Number of trees per ha was nearly 9100 individuals (considering trees with height over $10 \mathrm{~cm}$ ), mean (Lorey's) tree height was $4.6 \mathrm{~m}$, mean diameter measured at stem base was $6.7 \mathrm{~cm}$. While European larch was planted at the site, all other tree species originated from natural regeneration. Previous measurements (see Konôpka et al. 2017) showed that the main part of stand biomass was accumulated in silver birch, Norway spruce and European larch. Although Norway spruce had much more individuals per spatial unit than silver birch, main stand canopy was built exclusively by silver birch. In spite of about the same tree age, birches overgrew the other tree species. Thus, inter-tree competition of silver birches in the main canopy was either non-existing (scattered individuals) or only intra-specific (birch clusters).

We selected 20 individuals of silver birch (all were 14-year-old that was proved later on discs at stem bases) equally divided into four different competition classes (i.e. five trees per class), specifically (Fig. 1):

0 - competition free crowns: the upper half of crown without any competition from neighbours,

1 - crowns under mild competition: the upper half of crown influenced by crown neighbours from one side,

2 - crowns under moderate competition: the upper half of crown influenced by crown neighbours from two sides,

3 - crowns under severe competition: the upper half of crown influenced by crown neighbours from at least three sides.

The selected trees were felled with a chain saw at ground surface. For a detailed analysis of foliage, we randomly sampled 5 leaves from the upper, middle and lower third of the crown, totalling 15 leaves from the whole crown (i.e. 300 leaves from all sampled trees). Leaves were packed in labelled (tree code and position in crown) paper envelopes. Afterwards, branches with foliage were cut off from the stems and packed in labelled (tree code) paper bags. The stem length (tree height) as well as stem diameters at breast height, i.e. $130 \mathrm{~cm}$ from the ground level (DBH), at $25 \%$ and $75 \%$ of tree height $\left(D_{25 \%}\right.$ and $D_{75 \%}$, respectively) were measured. Stems were cut into 1-m-long sections and packed in marked bags. All tree samples were transported to laboratory.

Bark was manually removed from stems using a knife, and foliage was removed from branches with fingers. Individual tree components, i.e. stem wood, stem bark, branches and foliage, of each tree were packed in paper bags and oven-dried under $95^{\circ} \mathrm{C}$ till their weight stabilised (i.e. foliage for circa 24 hours, bark for 48 hours, branches for 72 hours and stems for 96 hours). All components were weighed with a precision of $0.1 \mathrm{~g}$.

Foliage subsamples taken for the detailed analysis were stored in a refrigerator till further processing. Each leaf was scanned and its area was calculated using the Easy Leaf Area software (Easlon \& Bloom 2014). The leaves were oven-dried (under $95^{\circ} \mathrm{C}$ for 12 hours) and weighed with a precision of $0.001 \mathrm{~g}$.

The following variables were recorded for each tree and used for further calculations: tree height, $\mathrm{DBH}, \mathrm{D}_{25 \%}$ and $\mathrm{D}_{75 \%}$, area of individual leaves (from three vertical levels of crown) and their dry weight, i.e. leaf biomass, total foliage biomass, branch biomass, stem wood and stem bark biomass.

From these variables we derived biomass models for individual tree components using the following two equations:

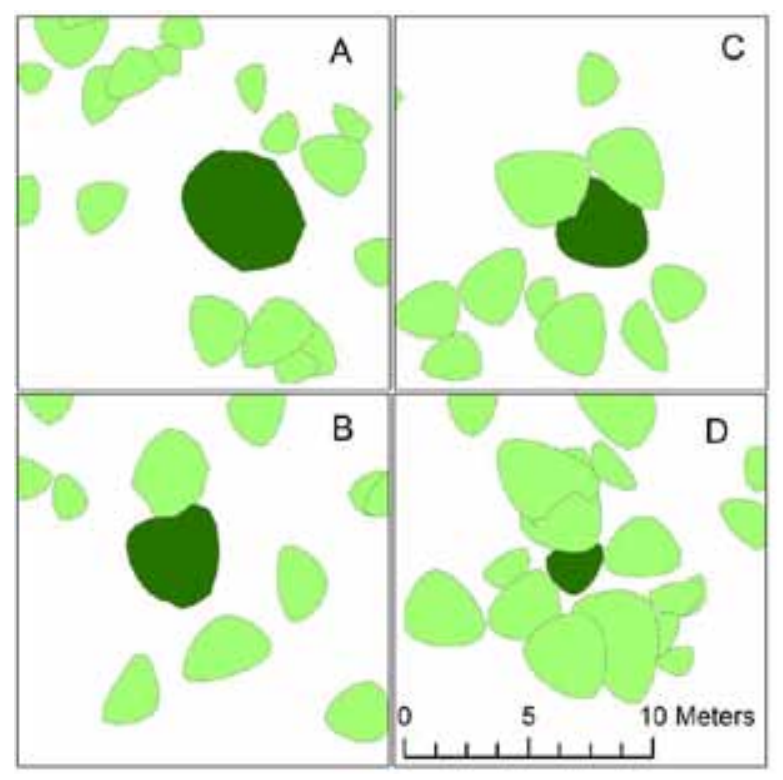

Fig. 1. Examples of the competition classes in sampled silver birches (dark colour indicates a target tree) recorded in the research site, specifically: 0 - competition free crown (scheme A), 1 - crown under mild competition (scheme B), 2 - crown under moderate competition (scheme $C$ ) and 3 - crown under severe competition (scheme D). The position of the trees and their crown projection were measured by the Field-Map technology (used exclusively for illustration of four competition classes). 


$$
\begin{aligned}
& B_{i}=a D B H^{b} \\
& B_{i}=a h^{b}
\end{aligned}
$$

where:

$B_{i} \quad$ - the biomass of the $\mathrm{i}$-th component in $\mathrm{kg}$ (i is the tree component, i.e. - stem divided into wood and bark, branches, foliage, or above-ground biomass),

$D B H$ - the breast height diameter in cm,

$h \quad$ - the tree height in $\mathrm{m}$, and

$a, b$ - parameters of the equation.

The total leaf area (LA) for each tree was calculated by multiplying the weight of all tree foliage and the average Specific leaf area (SLA; expressed in $\mathrm{cm}^{2}$ per $\mathrm{g}$ ):

$$
L A=B_{\text {foliage }} S L A
$$

The average tree-level SLA was determined as an arithmetic mean of 15 leaf samples that were taken from the individual tree.

The two-factor analysis of variance and the Fischer LSD test were used to create homogeneous groups to determine the dependence of leaf weight, leaf area and SLA of individual trees on the position of leaves in the crown (upper, middle and lower crown) and the competition class. Based on this test, homogeneous groups were also formed when testing the dependence of proportions and on the competition class of trees.

All statistical analyses were performed in Statistica 10.0 and R program (R Development Core Team 2012).

\section{Results}

Heights of silver birch sampled trees varied between $6.3 \mathrm{~m}$ and $12.4 \mathrm{~m}$ and DBH between $6.4 \mathrm{~cm}$ to $23.1 \mathrm{~cm}$ (Fig. 2). It means that the variance of DBH was nearly double of that in tree height. Both tree height and DBH varied between the competition classes. Specifically, tree heights in class 0 were from 9.6 to $11.7 \mathrm{~m}$, in class 1 the interval was $9.1-12.4 \mathrm{~m}$, in class 2 it was $6.7-10.7 \mathrm{~m}$ and in class 3 it was $6.3-10.3 \mathrm{~m}$. As for $\mathrm{DBH}$, the intervals were as follows: tree category 0 from 18.3 to $23.1 \mathrm{~cm}$, tree category 1 between 13.9 and $22.0 \mathrm{~cm}$, tree category 2 from 10.7 to $14.5 \mathrm{~cm}$ and tree category 3 between 6.4 and $10.9 \mathrm{~cm}$ (see also Table 1 ).

Table 1. Mean tree height, diameter DBH, $D_{25 \%}$ and $D_{75 \%}$ for the sampled silver birches in the separate competition classes $(0$ - competition free crown, 1 - crown under mild competition, 2 - crown under moderate competition, and 3 - crown under severe competition). Values in brackets are standard deviations. Different index letters within columns indicate significant differences between the competition classes separately for each tree characteristics (LSD test with $\alpha=0.05$ ).

\begin{tabular}{lcccc}
\hline $\begin{array}{c}\text { Competition } \\
\text { class }\end{array}$ & $\begin{array}{c}\text { Tree height } \\
{[\mathrm{m}]}\end{array}$ & Diameter DBH & Diameter $\mathrm{D}_{25 \%}$ & Diameter $\mathrm{D}_{75 \%}$ \\
\cline { 3 - 5 } & $10.80(0.80)^{\mathrm{ab}}$ & $21.4(1.9)^{\mathrm{a}}$ & $17.2(1.5)^{\mathrm{a}}$ & $4.4(0.8)^{\mathrm{a}}$ \\
1 & $11.08(1.34)^{\mathrm{a}}$ & $11.08(1.34)^{\mathrm{a}}$ & $14.0(2.5)^{\mathrm{b}}$ & $4.2(0.7)^{\mathrm{a}}$ \\
2 & $9.09(1.62)^{\mathrm{bc}}$ & $9.09(1.62)^{\mathrm{bc}}$ & $10.8(1.5)^{\mathrm{c}}$ & $3.6(1.2)^{\mathrm{a}}$ \\
3 & $8.24(1.47)^{\mathrm{c}}$ & $8.24(1.47)^{\mathrm{c}}$ & $7.5(1.5)^{\mathrm{d}}$ & $3.4(0.8)^{\mathrm{a}}$ \\
\hline
\end{tabular}

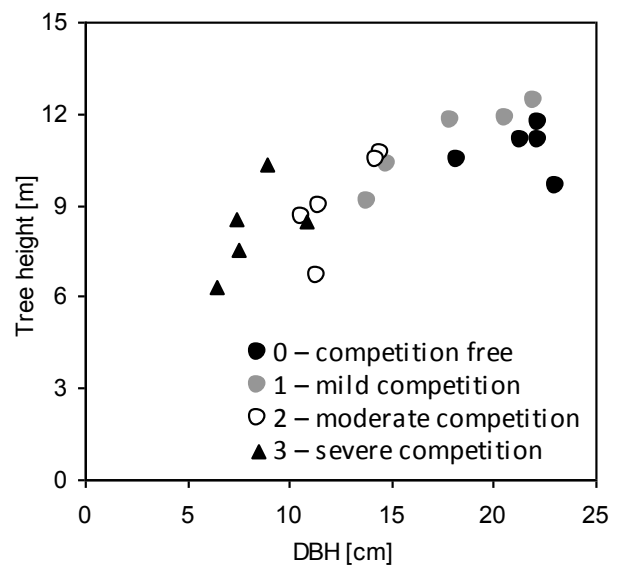

Fig. 2. Tree heights and breast height diameter (DBH) of sampled silver birches with indication of the specific competition classes $(0-$ competition free crown, 1 - crown under mild competition, 2 - crown under moderate competition, and 3 crown under severe competition).

Our models (Table 2) expressing biomass of specific tree components, total aboveground biomass and total foliage area showed that DBH was a better explanatory variable than tree height due to a closer relationship with biomass (see values of $\mathrm{p}, \mathrm{R}^{2}$, and mean square error in Table 2). The largest biomass proportion was allocated in stem biomass, followed by branches and foliage (Fig. 3). For instance, while biomass of birches with DBH of $10 \mathrm{~cm}$ contained about $12 \mathrm{~kg}$ of stem, $4 \mathrm{~kg}$ of branches and $1.5 \mathrm{~kg}$ of foliage, birches with DBH of $20 \mathrm{~cm}$ made up $60 \mathrm{~kg}$ of stem, $30 \mathrm{~kg}$ of branches and $7.5 \mathrm{~kg}$ of foliage. It means that trees with DBH of $20 \mathrm{~cm}$ had about three times larger biomass (around $90 \mathrm{~kg}$ ) than those with DBH of $10 \mathrm{~cm} \mathrm{(30} \mathrm{kg).} \mathrm{As} \mathrm{for} \mathrm{total} \mathrm{foliage} \mathrm{area} \mathrm{(Fig.} \mathrm{4),}$ birches with DBH of $20 \mathrm{~cm}$ had nearly three times higher values (about $115 \mathrm{~m}^{2}$ ) than individuals with $\mathrm{DBH}$ equal $10 \mathrm{~cm}\left(35 \mathrm{~m}^{2}\right)$.

Further we focused on intra-specific influence on stem shape, specifically slenderness ratio (Fig. 5 top) and taper ratio (Fig. 5 bottom). Both indicators reached the lowest values in trees with no crown competition and the highest values in the case of trees under severe crown competition. This means that trees without crown competition had a more converging stem shape (a cone-like stem) than trees under severe crown competition (with a cylinder-like stem).

Crown competition modified not only stem shape but also allocation of biomass to tree components (Table 3). Specifically, birches with severe crown competition had a higher ratio of foliage biomass to branch biomass (0.344) than competition-free ones (0.179). At the same time, the ratio of branch biomass to stem biomass was higher in crown competition-free birches $(0.603)$ than for the birches under severe crown competition $(0.352)$. Moreover, the comparison of crown competition-free birches to those under severe competition (i.e. tree categories with contrasting statuses) showed very different relative con- 
Table 2. Allometric relations for biomass of stem (over or under bark), stem bark, branches, foliage, aboveground parts together and total foliage area in silver birch. Shapes of formulas are $B_{i}=a D B H^{b}$ if using breast height diameter (DBH) and $B_{i}=a h^{b}$ if using tree height as independent variable. Abbreviations a and $b$ are parameters, S.E. are standard errors, $p$ is $p-$ value, $R^{2}$ is coefficient of determination, and MSE is mean square error.

\begin{tabular}{|c|c|c|c|c|c|}
\hline Tree component [unit)] & $\begin{array}{l}\text { Independent variable } \\
\text { [unit[ }\end{array}$ & a (S.E.) $p$ & b (S.E.) $p$ & $\mathrm{R}^{2}$ & MSE \\
\hline \multirow{2}{*}{ Stem over bark - biomass [kg] } & $\mathrm{DBH}[\mathrm{cm}]$ & $0.186(0.080) 0.032$ & $1.982(0.143)<0.001$ & 0.957 & 44.09 \\
\hline & Tree height [m] & $0.00516(0.010) 0.606$ & $3.9070 .788<0.001$ & 0.710 & 296.51 \\
\hline \multirow{2}{*}{ Stem under bark - biomass $[\mathrm{kg}]$} & $\mathrm{DBH}[\mathrm{cm}]$ & $0.106(0.055) 0.071$ & $2.087(0.173)<0.001$ & 0.946 & 35.87 \\
\hline & Tree height $[\mathrm{m}]$ & $0.00203(0.004) 0.635$ & $4.1890 .856<0.001$ & 0.707 & 195.62 \\
\hline \multirow{2}{*}{ Stem bark-biomass [kg] } & $\mathrm{DBH}[\mathrm{cm}]$ & $0.118(0.049) 0.027$ & $1.629(0.140)<0.001$ & 0.930 & 2.81 \\
\hline & Tree height [m] & $0.00877(0.014) 0.524$ & $3.0630 .644<0.001$ & 0.682 & 12.81 \\
\hline \multirow{2}{*}{ Branches - biomass [kg] } & $\mathrm{DBH}[\mathrm{cm}]$ & $0.014(0.012) 0.237$ & $2.633(0.269)<0.001$ & 0.931 & 27.65 \\
\hline & Tree height [m] & $0.00305(0.010) 0.753$ & $\begin{array}{lll}3.852 & 1.297 & 0.008\end{array}$ & 0.457 & 218.78 \\
\hline \multirow{2}{*}{ Foliage - biomass [kg] } & $\mathrm{DBH}[\mathrm{cm}]$ & $0.036(0.018) 0.063$ & $1.792(0.169)<0.001$ & 0.923 & 0.87 \\
\hline & Tree height [m] & $0.00125(0.002) 0.613$ & $3.5790 .805<0.001$ & 0.640 & 4.11 \\
\hline \multirow{2}{*}{ Aboveground parts together-biomass [kg] } & $\mathrm{DBH}[\mathrm{cm}]$ & $0.186(0.072) 0.018$ & $2.149(0.127)<0.001$ & 0.972 & 83.4 \\
\hline & Tree height [m] & $0.00921(0.021) 0.662$ & $3.8680 .931<0.001$ & 0.627 & 1109.18 \\
\hline \multirow{2}{*}{ Foliage - total area $\left[\mathrm{m}^{2}\right]$} & $\mathrm{DBH}[\mathrm{cm}]$ & $1.470(0.788) 0.078$ & $1.4620 .181<0.001$ & 0.864 & 316.46 \\
\hline & Tree height [m] & $0.048(0.770) 0.540$ & $3.205(0.666)<0.001$ & 0.667 & 773.09 \\
\hline
\end{tabular}

Table 3. Ratio between quantities of particular tree component in silver birch with regard to competition class $(0-$ competition free crown, 1 - crown under mild competition, 2 - crown under moderate competition, and 3 - crown under severe competition). Mean values and standard deviations are shown. Index letters indicate statistical differences between tree competition classes (separately for each row; LSD test with $\alpha=0.05$ ).

\begin{tabular}{|c|c|c|c|c|c|}
\hline \multirow{2}{*}{$\begin{array}{l}\text { Relationship between components } \\
\text { versus competiton class }\end{array}$} & \multicolumn{4}{|c|}{ Competition class } & \multirow{2}{*}{ All trees } \\
\hline & 0 & 1 & 2 & 3 & \\
\hline Foliage biomass $[\mathrm{kg}]$ / branch biomass [kg] & $0.179(0.037)^{\mathrm{a}}$ & $0.264(0.069)^{\mathrm{ab}}$ & $0.287(0.090)^{b}$ & $0.344(0.059)^{b}$ & $0.269(0.064)$ \\
\hline Foliage biomass $[\mathrm{kg}] /$ stem biomass $[\mathrm{kg}]$ & $0.105(0.024)^{\mathrm{a}}$ & $0.116(0.069)^{\mathrm{a}}$ & $0.139(0.022)^{\mathrm{a}}$ & $0.126(0.076)^{\mathrm{a}}$ & $0.122(0.034)$ \\
\hline Foliage biomass [kg] / branch + stem biomass [kg] & $0.066(0.015)^{\mathrm{a}}$ & $0.080(0.016)^{\mathrm{a}}$ & $0.091(0.022)^{\mathrm{a}}$ & $0.089(0.043)^{\mathrm{a}}$ & $0.081(0.019)$ \\
\hline Branch biomass $[\mathrm{kg}]$ / stem biomass $[\mathrm{kg}]$ & $0.603(0.115)^{\mathrm{a}}$ & $0.453(0.079)^{\mathrm{ab}}$ & $0.542(0.262)^{\mathrm{ab}}$ & $0.352(0.156)^{b}$ & $0.488(0.153)$ \\
\hline Foliage area $\left[\mathrm{m}^{2}\right] /$ branch biomass $[\mathrm{kg}]$ & $2.699(0.906)^{\mathrm{a}}$ & $4.471(1.298)^{\mathrm{ab}}$ & $5.144(2.092)^{\mathrm{b}}$ & $6.252(1.493)^{b}$ & $4.641(1.447)$ \\
\hline Foliage area $\left[\mathrm{m}^{2}\right] /$ stem biomass $[\mathrm{kg}]$ & $1.559(0.319)^{\mathrm{a}}$ & $1.983(0.564)^{\mathrm{a}}$ & $2.434(0.378)^{\mathrm{a}}$ & $2.244(1.025)^{\mathrm{a}}$ & $2.055(0.671)$ \\
\hline Foligae area $\left[\mathrm{m}^{2}\right] /$ branch + stem biomass $[\mathrm{kg}]$ & $0.981(0.243)^{\mathrm{a}}$ & $1.366(0.370)^{\mathrm{a}}$ & $1.597(0.274)^{\mathrm{a}}$ & $1.596(0.807)^{\mathrm{a}}$ & $1.385(0.424)$ \\
\hline
\end{tabular}
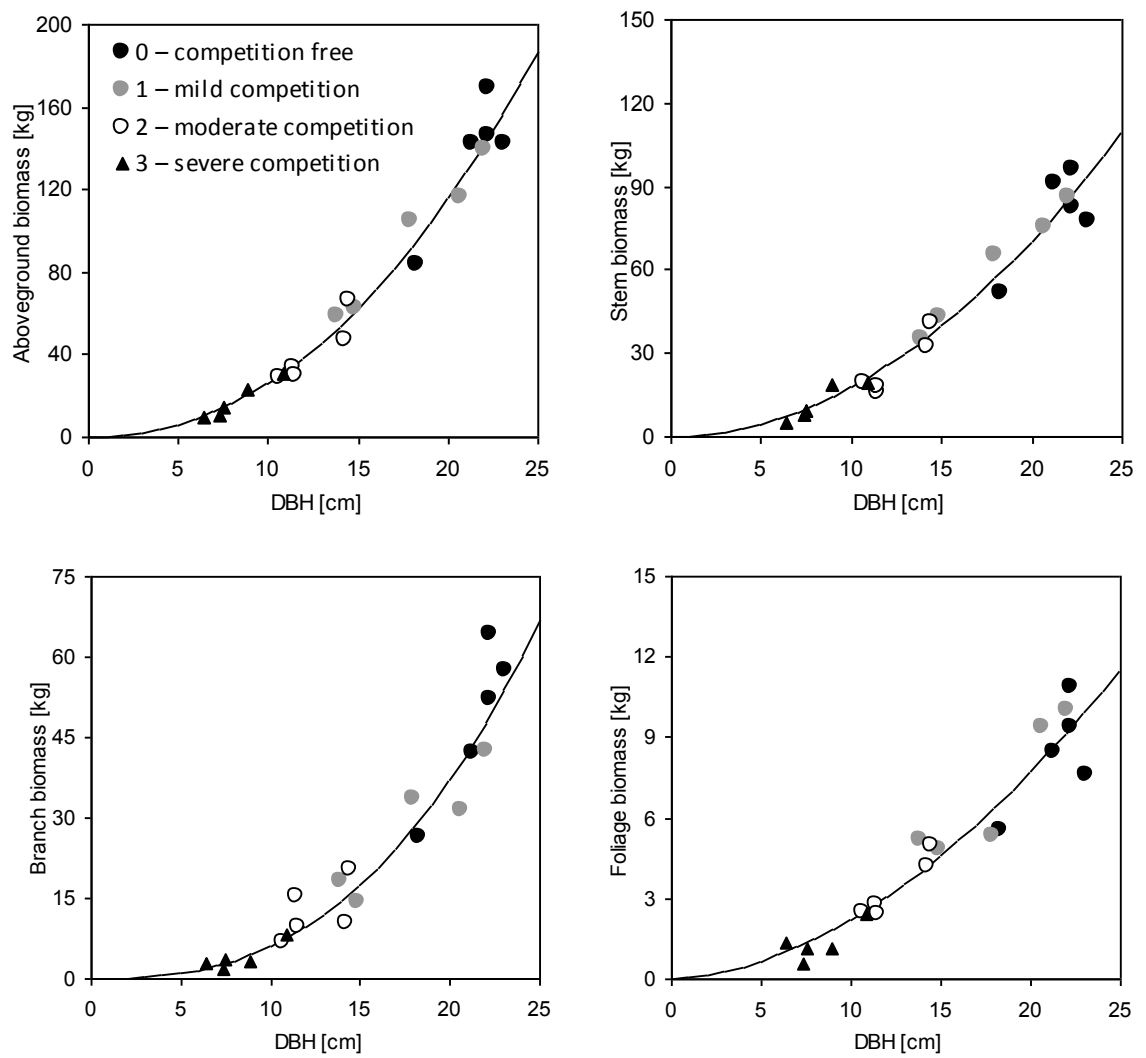

Fig. 3. Relationship between breast height diameter (DBH) and aboveground biomass (top left), stem biomass (top right), branch biomass (bottom left), foliage biomass (bottom right) of silver birch trees with indication of the specific crown competition classes ( 0 - competition free crown, 1 - crown under mild competition, 2 - crown under moderate competition, and 3 crown under severe competition). The fitted formula is: $B_{i}=a D B H^{b}$, values of parameters are in Table 2 . 


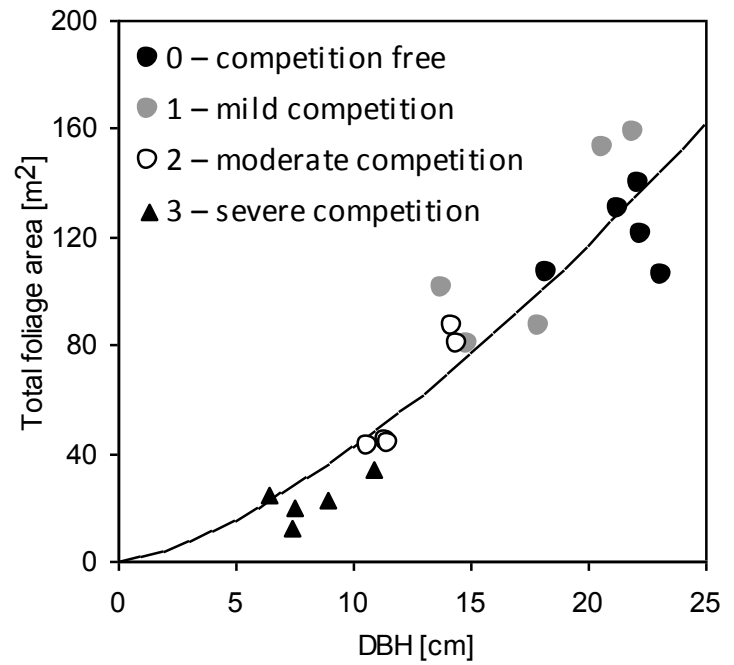

Fig. 4. Relationship between total foliage area and breast height diameter $(\mathrm{DBH})$ of silver birch trees with indication of the specific crown competition classes $(0$ - competition free crown, 1 - crown under mild competition, 2 - crown under moderate competition, and 3 - crown under severe competition). The fitted formula is: $B_{i}=a D B H^{b}$ (values of parameters are in Table 2).

tribution of individual components to total aboveground biomass (Fig. 6). While in competition-free birches the contribution of foliage, branches and stem was $6 \%, 36 \%$, and $58 \%$, respectively, in the case of birches under severe crown competition $8 \%$ of aboveground biomass was in foliage, $22 \%$ in branches and $70 \%$ in stem. Moreover, the results suggested a higher ratio between foliage area and branch biomass in competition severely stressed birches $\left(6.25 \mathrm{~m}^{2} \mathrm{~kg}^{-1}\right)$ than in crown competition-free trees (2.70 $\mathrm{m}^{2} \mathrm{~kg}^{-1}$, Table 3).

Intensity of crown competition influenced also foliage traits, specifically foliage weight (Fig. 7 - top left) and SLA (Fig. 6 - bottom), but not much foliage area (Fig. 7 - top right; see also Table 4). Both, foliage weight and SLA, of crown competition-free birches differed from those under certain levels of competition stress, mainly from severely stressed trees. The results indicated that foliage traits were more dependent on foliage position along the vertical crown profile than on intra-specific tree competition (Table 4). At the same time, differences in foliage weight between competition classes (i.e. 0 versus 1, 2 and 3) were clear in the upper part of crown, and for SLA in the upper and middle parts of crown. Statistical analyses (ANOVA and LSD test; see Fig. 7 and Table 4) suggested that the influence of individual factors (competition class or foliage position in crown) is stronger than their combined effect (competition class and foliage position in crown together).

\section{Discussion}

\subsection{Aboveground biomass allocation and crown competition}

Our stand specific biomass models for silver birch indicated that stem diameter, specifically DBH, is a better explanatory variable (higher values of $p, R^{2}$ and MSE) than tree height. This result supports previously published works (e.g. Johansson 1999; Hochbichler et al. 2006; Pajtík et al. 2008; Wang et al. 2011) that proved stem diameter as the most important independent variable for predicting total tree biomass or biomass of individual components. Our paper showed that this principle is valid not only for tree biomass but also for total foliage area.
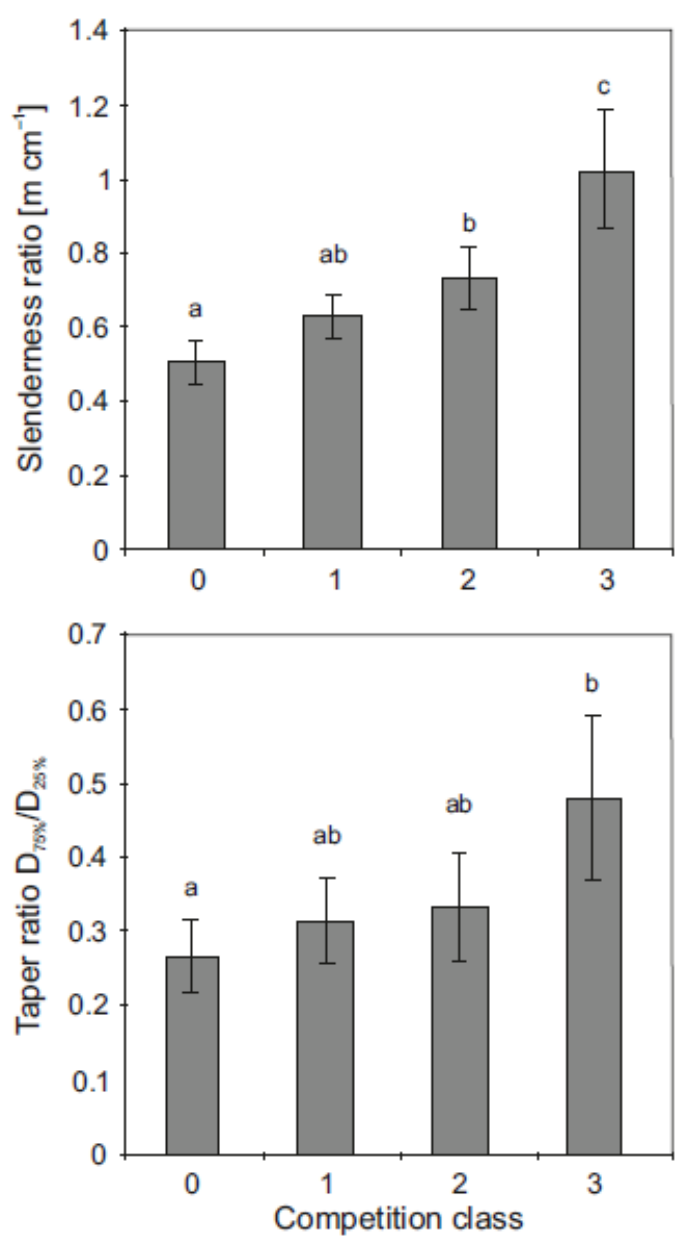

Fig. 5. Slenderness ratio (top) defined as a ratio of tree height to breast height diameter and taper ratio (bottom) calculated from diameters at $25 \%$ and $75 \%$ tree height in silver birches classified in competition classes $(0-$ competition free crown, 1 - crown under mild competition, 2 - crown under moderate competition, and 3 - crown under severe competition). Different letters indicate significant differences between competition classes (LSD test with $\alpha=0.05$ ). Error bars indicate standard deviations. 


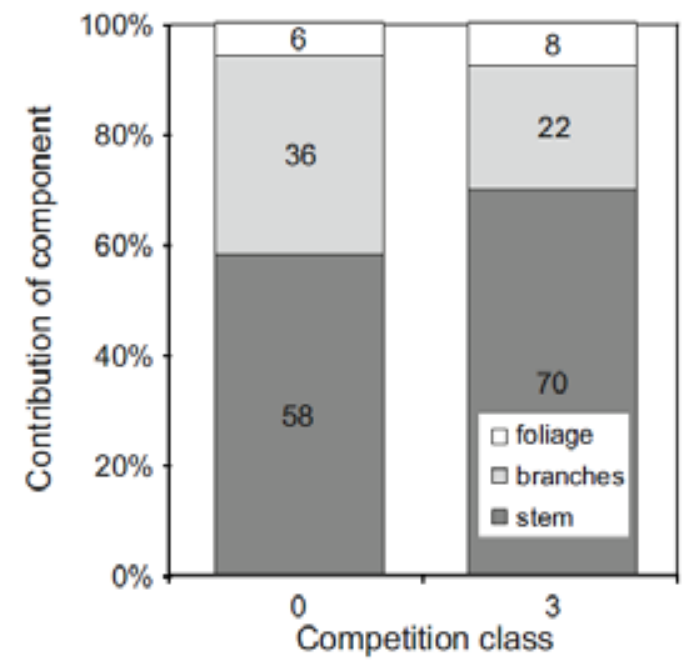

Fig. 6. Comparison on contribution of tree components to aboveground biomass between contrasting tree competition classes, i.e. 0 (competition free crown) versus 3 (crown under severe competition).
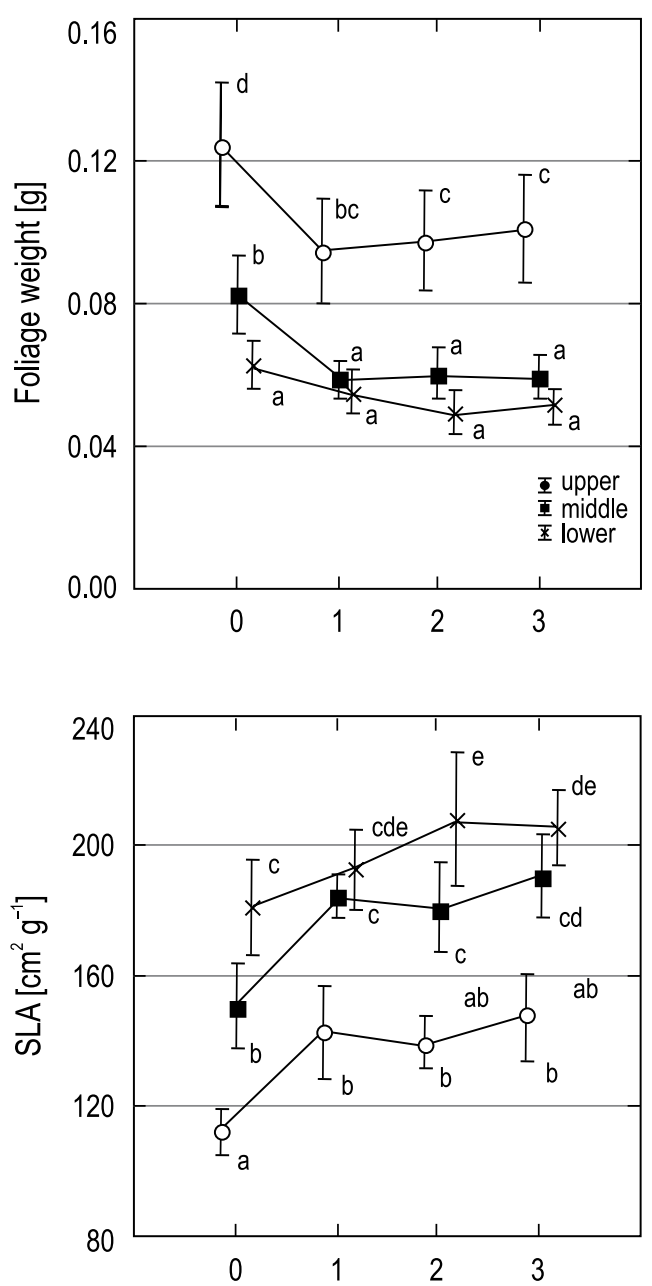

The crown-competition free birches reached a height of nearly $13 \mathrm{~m}$, and accumulated as much as $150 \mathrm{~kg}$ of aboveground biomass at the age of 14 . The average height ( \pm standard deviation) of all sampled trees was $9.80 \pm 1.73 \mathrm{~m}$, which coincided with the height of 14 -yearold trees according to several birch tables from Northern Europe (Kund et al. 2010). Eriksson et al. (1997) pointed out that birch is typical with rapid early growth, and at best sites it can reach a height of up to $24-25 \mathrm{~m}$ within 30 years. Similarly, Uri et al. (2007) stressed its fast growth and great production potential. However, birches maintain their vitality and vigorous growth only when growing as dominant trees in a stand with a relatively wide spacing and low degree of within-stand competition (Hynynen et al. 2010). Our measurements showed that crown competition-free silver birches made up approximately five times more aboveground biomass than those under severe crown competition. Generally, since "European" birch species are considered as shade intolerant, lack of light can robustly retard their growth (San-Miguel-Ayanz et al. 2016). Field experiment conducted in Sweden

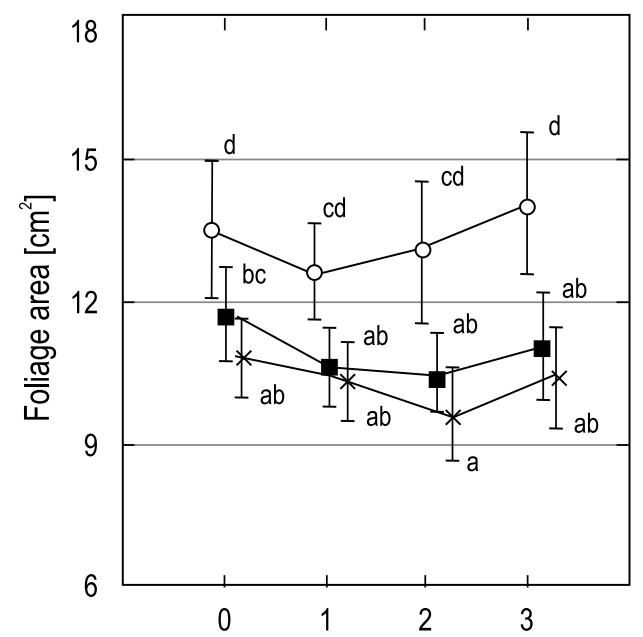

Fig. 7. Individual dry foliage weight (top left), foliage area (top right) and specific leaf area (SLA; bottom) with regard to competition classes $(0$ - competition free crown, 1 - crown under mild competition, 2 - crown under moderate competition, and 3 - crown under severe competition) and position in the crown of silver birches. Different letters indicate significant differences between tree competition classes (LSD test with $\alpha=0.05$ ). 
Table 4. Statistical characteristics related to tree competition classes $(0$ - competition free crown, 1 - crown under mild competition, 2 - crown under moderate competition, and 3 - crown under severe competition) and position in crown to foliage traits in silver birch (LSD test).

\begin{tabular}{lccc}
\hline \multirow{2}{*}{ Factor versus foliage trait } & Foliage weight $[\mathrm{g}]$ & Foliage area $\left[\mathrm{cm}^{2}\right)$ & Specific leaf area $\left[\mathrm{cm}^{2} \mathrm{~g}^{-1}\right]$ \\
\cline { 2 - 4 } & \multicolumn{3}{c}{$\mathrm{df}(\mathrm{F}$-value) $\mathrm{p}$-value } \\
\hline Competition class & $3.276(11.551)<0.001$ & $3.276(2.322) 0.075$ & $3.276(16.553)<0.001$ \\
Position in crown & $2.276(108.41)<0.001$ & $2.276(34.614)<0.001$ & $2.276(102.11)<0.001$ \\
Compettion class x position in crown & $6.276(0.948) 0.0461$ & $6.276(0.439) 0.852$ & $6.276(0.835) 0.543$ \\
\hline
\end{tabular}

(Johansson 2007) showed that in young growth stages silver birch is more productive (total biomass production) than downy birch.

Our results showed that competition intensity in birch crowns modified aboveground biomass allocation pattern. While the proportions of aboveground biomass components in competition-free individuals were $6 \%$ (foliage), 36\% (branches) and 58\% (stem), these proportions in birches under severe competition were: $8 \%: 22 \%$ :70\%.Although proportions between foliage biomass to stem biomass as well as foliage biomass to branch + stem biomass did not significantly differ between tree categories, competition stress increased the ratio of foliage to branch biomass but decreased the branch to stem biomass ratio (Table 3). Changes in biomass partitioning to plant organs is an important mechanism to maintain productivity (Sebastia 2007). Commonly respected the Optimal Partitioning Theory assumes that plants allocate more biomass to organs that have limited access to resources (Bloom et al. 1985). For instance, in nutrient-limited soil conditions, plants decrease biomass allocation to foliage and increase biomass allocation to roots (Poorter et al. 2012; Deng et al. 2006). Similar effect has been observed in the case of reduced water availability (Hommel et al. 2016; Friendligstein et al. 1999). Lack of light due to e.g. severe crown competition causes the opposite, i.e. more biomass is allocated to foliage (Fig. 6; Poorter et al. 2012; Konôpka et al. 2016). At the same time, trees under intensive competition (light insufficiency) attempt to increase allocation to stem to increase their height instead of branches (Fig. 6, Wang et al. 2011). Recently Yang et al. (2019) showed in Quercus liaotungensis that competition intensity decreased ratio between branch and stem biomass, but other ratios (foliage to stem and foliage to branch) have not changed significantly.

\subsection{Stem traits with regard to crown competition}

Our results indicated that birches under severe competition stress attempt to invest more biomass in height increment in relative expression to diameter increment in comparison to competition-free trees. Consequently, more stressed trees have slender and relatively high stems with more conic shapes. On the other hand, competitionfree birches have thicker stems and their stem forms are closer to a cylinder-like shape. The shape of a tree stem is important for tree resistance against wind or snow dam- age (e.g. Konôpka \& Konôpka 2003; Bošela et al. 2014) and for timber quality (Oker-Blom et al.1988). Snowdon et al. (1981) explained that the shape of a tree stem (bole) could be characterised by at least two basic features: taper and form. Stem taper has been frequently expressed as a ratio between tree height and stem diameter, usually DBH (i.e. slenderness ratio; e.g. Wang et al. 1998; Opio et al. 2000; Sharma et al. 2016). Stem form was studied rather occasionally, mostly as a ratio between stem diameters measured at two different sections of the bole, mostly at $25 \%$ versus $75 \%$ of tree height (e.g. Wiklund et al.1995). The previous papers showed that the stem taper changes not only due to tree competition but is also ruled by soil conditions, i.e. both nutrients and water status (Wiklund et al. 1995), and stand age (Bošela et al. 2014).

Experiments focusing on initial tree spacing and/or thinning intensity (tree reduction) in forest stands proved that the values of slenderness ratio always increased with stand density (e.g. Mäkinen et al. 2002; Harrington et al. 2009). At the same time, stand density is closely related to tree competition occurring between neighbouring individuals and involves the competition for light resources as well as for aboveground space in canopy, and/or for soil water and nutrients and for the room in soil between belowground root systems (Song et al. 2012). Nilsson (1993) suggested slenderness ratio as a reasonable indicator of competition intensity. Significant increase of slenderness ratio due to competition stress has been proved also in recent works focusing on Larix principisrupprechtii (Zhou et al.2018) and Quercus liaotungensis (Yang et al. 2019).

\subsection{Foliage traits with regard to crown competition}

Changes in plant leaf morphology are commonly believed to be dependent on growth conditions (Niinemets et al. 2007). Our results indicated that crown competition partly modified foliage weight and SLA. These changes were clear in the upper part of birch crowns. Foliage area was influenced by crown competition only negligibly (Fig. 7). Our main finding is that foliage position (upper, middle or lower third of crown) affected foliage properties more than crown competition among neighbours. Interactive effects of intra-species crown competition and foliage position on foliage properties were negligible. This can be most probably explained by the strong shading effect in the lower parts of crowns caused by branches 
and foliage situated in middle and upper portions of tree crowns. This effect might be so intense that the additional influence from crowns of neighbouring birches did not further contribute to the final status of foliage in the lower parts of crowns.

Leaf is the only plant organ with the capacity to capture energy and drive growth. Foliage responds to growth conditions within a stand very sensitively, and has been shown to adapt its morphology accordingly (Bussotti et al. 2000). Greater SLA with increasing shading is likely a plant adaptation to low light conditions that ensures light interception (Niinemets et al. 2001). Considering the effect of shading on SLA, mean SLA of small (overtopped) trees is greater than of dominant trees, but the value approximates to that of spruce and beech larger (dominant) individuals (Konôpka et al. 2016). Higher SLA of shaded foliage inyoung beech stands was recorded for instance by Closa et al. (2010). Barna (2004) showed lower values of SLA in dominant and co-dominant beech trees than in subdominant individuals.

Our results clearly showed that tree competition influences not only tree size but also biomass allocation, stem shape and foliage properties. Since these kinds of findings were missing for silver birch, the results can throw more light on production, physiology as well as ecology of this tree species. Enhanced knowledge on the drivers of biomass allocation is also helpful for forest growth modelling (Merganičová et al. 2019), since allocation has been considered as one of the main weaknesses of simulation models (Le Roux et al. 2001; Richardson et al. 2015). As silver birch is not an ecologically demanding species, but it is very productive (although rather shortliving), it would very probably be a perspective species in the conditions of the ongoing climate change and also in the period of intensified utilisation of renewable resources (especially for energy and pulp). Thus, further studies of this species are still requisite.

\section{Acknowledgements}

The research was supported by the projects APVV-18-0086 and $A P V V$-15-0265 from the Slovak Research and Development Agency, and by grant "EVA4.0", No. CZ.02.1.01/0.0/ 0.0/16_019/0000803 financed by OP RDE, as well as by the project "Research and innovation for supporting competitiveness of the Slovak forestry sector" (SLOV-LES) financed by the Ministry of Land Management and Rural Development of the Slovak Republic.

\section{References}

Barna, M., 2004: Adaptation of European beech (Fagus sylvatica L.) to different ecological conditions: leaf size variation. Polish Journal of Ecology, 52:35-45.
Bloom, A.J., Chapin, F. S., Mooney, H.A., 1985: Resource limitation in plants - an economic analogy. Annual Review of Ecology and Systematics, 16:363-392.

Bošela, M., Konôpka, B., Šebeň, V., Vladovič, J., Tobin, B., 2014: Modelling height to diameter ratio - An opportunity to increase Norway spruce stand stability in the Western Carpathians. Lesnícky časopis Forestry Journal, 60:71-80.

Bronisz, K., Strub, M., Cieszewski, Ch., Bijak, S., Bronisz, A., Tomusiak, R. et al., 2016: Empirical equations for estimating aboveground biomass of Betula pendula growing on former farmland in central Poland. Silva Fennica, 50:1-17.

Bussotti, F., Borghini, F., Celesti, C., Leonzio, C., Bruschi, P., 2000: Leaf morphology and macronutrients in broadleaved trees in central Italy. Trees, 14:361-368.

Cotrufo, M. F., Ineson, P., Roberts, D., 1995: Decomposition of birch leaf litters with varying $\mathrm{C}$-to-N ratios. Soil Biology and Biochemistry, 27:1219-1221.

Claesson, S., Sahlén, K., Lundmark, T., 2001: Functions for biomass estimation of young Pinus sylvestris, Picea abies and Betula spp. from stands in northern Sweden with high stand densities. Scandinavian Journal of Forest Research, 16:138-146.

Closa, I., Irigoyen, J. J., Goicoechea, N., 2010: Microclimatic conditions determined by stem density influence leaf anatomy and leaf physiology of beech (Fagus sylvatica L.) growing within stands that naturally regenerate from clear-cutting. Trees, 24:1029-1043.

Deng, J. M., Wang, G. X., Morris, E. C., Wei, X. P., Li, D. X., Chen, B. M. et al., 2006: Plant mass-density relationship along a moisture gradient in north-west China. Journal of Ecology, 94:953-958.

Easlon, H. M., Bloom, A. J., 2014: Easy Leaf Area: Automated digital image analysis for rapid and accurate measurement of leaf area. Applications in Plant Sciences, 2:1400033.

Eriksson, H., Johansson, U., Kiviste, A., 1997: A siteindex model for pure and mixed stands of Betula pendula and Betula pubescens in Sweden. Scandinavian Journal of Forest Research, 12:149-156.

Find'o, S., Petráš, R., 2007: Ekologické základy ochrany lesa protipoškodeniu zverou.Zvolen, National Forest Centre, $186 \mathrm{p}$.

Friedlingstein, P., Joel, G., Field, C. B., Fung, I. Y. 1999: Toward an allocation scheme for global terrestrial carbon models. Global Change Biology, 5:755-770.

Harrington, T. B., Harrington, C. A., DeBell, D., 2009: Effects of planting spacing and site quality on 25-year growth and mortality relationships of Douglas-fir (Pseudotsuga menziesii var. menziesii). Forest Ecology and Management, 258:18-25. 
Hochbichler, E., Bellos, P., Lick, E., 2006: Biomass functions for estimating needle and branch biomass of spruce (Picea abies) and Scots pine (Pinus sylvestris) and branch biomass of beech (Fagus sylvatica) and oak (Quercus robur and petrea). Austrian Journal of Forest Sciences, 123:35-46.

Hommel, R., Siegwolf, R., Zavadlav, S., Arend, M., Schaub, M., Galiano, L. et al., 2016: Impact of interspecific competition and drought on the allocation of new assimilates in trees. Plant Biology, 18:785-796.

Hynynen, J., Niemistö, P., Viherä-Aarnio, A., Brunner, A., Hein, S., Velling, P., 2010: Silviculture of birch (Betula pendula Roth and Betula pubescens Ehrh.) in northern Europe. Forestry, 83:103-119.

Jagodzinski, A. M., Zasada, M., Bronisz, K., Bronisz, A., Bijak, S., 2017: Biomass conversion and expansion factors for a chronosequence of young naturally regenerated silver birch (Betula pendula Roth) stands growing on post-agricultural sites. Forest Ecology and Management, 384:208-220.

Johansson, T., 1999: Biomass production of Norway spruce (Picea abies [L.] Karst.) growing on abandoned farmland. Silva Fennica, 33:261-280.

Johansson, T., 2007: Biomass production and an allometric above- and below-ground relations for young birch stands planted at four spacings abandoned farmland. Forestry, 80:41-52.

Kacálek, D., Mauer, O., Podrázský, V., Slodičák, M. et al., 2017: Soil improving and stabilizing functions of forest trees. Lesnická práce, 300 p.

Konôpka, B., Konôpka, J., 2003: Static stability of forest stands in the seventh altitudinal vegetation zone in Slovakia. Journal of Forest Science, 49:474-481.

Konôpka, B., Pajtík, J., Marušák, R., Bošela, M., Lukac, M., 2016: Specific leaf area and leaf area index in developing stands of Fagus sylvatica L. and Picea abies Karst. Forest Ecology and Management, 364:52-59.

Konôpka, B., Pajtík, J., Máliš, F., Šebeň, V., Mal'ová, M., 2017: Carbon stock in aboveground biomass of vegetation at the High Tatra Mts. twelve years after disturbance. Central European Forestry Journal, 63:142-151.

Konôpka, B., Šebeň, V., Pajtík, J., 2019: Species composition and carbon stock of tree cover at a postdisturbance area in Tatra National Park, Western Carpathians. Mountain Research and Development, 39:71-80.

Kula, E., 2011: Bříza a její význam pro trvalý rozvoj lesa v imisných oblastech. Prague, Publishing House for Forestry, $276 \mathrm{p}$.

Kunca, A., Zúbrik, M., Galko, J., Vakula, J., Leontovyč, R., Konôpka, B. et al., 2019: Salvage felling in the Slovak Republic's forests during the last twentyyears (1998-2017). Central European Forestry Journal, $1: 3-11$.
Kund, M., Vares, A., Sims, A., Tullus, H., Uri, V., 2010: Early growth and development of silver birch (Betula pendula Roth) plantations on abandoned agricultural land. European Journal of Forest Research, 129:679-688.

Kurvits, V., Ots, K., Kangur, A., Korjus, H., Muiste, P., 2020: Assessment of load and quality of logging residues from clear-felling areas in Järveselja: a case study from Southeast Estonia. Central European Forestry Journal, 66:3-11.

Lehtonen, A., Mäkipää, R., Heikkinen, J., Sievänen, J., Liski, J., 2004: Biomass expansion factors (BEFs) for Scots pine, Norway spruce and birch according to stand age for boreal forests. Forest Ecology and Management, 188:211-224.

Le Roux, X., Lacointe, A., Escobar-Gutierrez, A., Le Dizes, S., 2001: Carbon-based models of individual tree growth: A critical appraisal. Annals of Forest Science, 58:469-506.

Martiník, A., Knott, R., Krejza, J., Černý, J., 2018: Biomass production of Betula pendula stands regenerated in the region of allochthonous Pice abies dieback. Silva Fennica, 52:1-15.

Mäkinen, H., Nöjd, P., Isomäki, A., 2002: Radial, height and volume increment variation in Picea abies (L.) Karst. stands with varying thinning intensities. Scandinavian Journal of Forest Research, 2:227-228.

Mensah, S., Kakai, R.G., Seifert, T., 2016: Patterns of biomass allocation between foliage and woody structure: the effects of tree size and specific functional traits. Annals of Forest Research, 59:49-60.

Merganičová, K., Merganič, J., Lehtonen, A., Vacchiano, A., Ostrogović-Sever, M.Z., Augustynczik, A.L.D. et al., 2019: Forest carbon allocation modelling under climate change. Tree Physiology, 39:1937-1960.

Milla, R., Reich, P.B., Niinemets, U., Castro-Diez, P., 2008: Environmental and developmental controls on specific leaf area are little modified by leaf allometry. Functional Ecology, 22:565-576.

Nilsson, U., 1993: Competition in young stands of Norway spruce and Scots pine. Swedish University of Agricultural Sciences, Uppsala, PhD. Thesis, 173 p.

Niinemets, Ü., Ellsworth, D.S., Lukjanova, A., Tobias, M., 2001: Site fertility and the morphological and photosynthetic acclimation of Pinus sylvestris needles to light. Tree Physiology, 21:1231-1244.

Niinemets, U., Portsmuth, A., Tobias, M., 2007: Leaf Shape and Venation Pattern Alter the Support Investments within Leaf Lamina in Temperate Species: A Neglected Source of Leaf Physiological Differentiation, Functional Ecology, 21:28-40.

Oker-Blom, P., Kellomäki, S., Valtonen, E., Väisänene, H., 1988: Structural development of Pinus sylvestris stands with varying initial density: a simulation model. Scandinavian Journal of Forest Research, 3:185-200. 
Opio, C., Jacob, N., Coopersmith, D., 2000: Height to diameter ratio as a competition index for young conifer plantations in northern British Columbia, Canada. Forest Ecology and Management, 137:245-252.

Pajtík, J., Konôpka, B., Lukac, M., 2008: Biomass functions and expansion factors in young Norway spruce (Picea abies [L.] Karst) trees. Forest Ecology and Management, 256:1096-1103.

Poorter, H., Niklas, K. J., Reich, P. B., Oleksyn, J., Poot, P., Mommer, L., 2012: Biomass allocation to leaves, stems and roots: meta-analyses of interspecific variation and environmental control. New Phytologist, 193:30-50.

R Development Core Team, 2012: R: A Language and Environment for Statistical Computing. Vienna: $\mathrm{R}$ foundation for Statistical Computing. Webpage: http://www.R-project.org/

Repola, J., 2008: Biomass equations for birch in Finland. Silva Fennica, 42:605-624.

Richardson, A. D., Carbone, M. S., Huggett, B. A., Furze, M. E., Czimczik, C. I., Walker, J. C. et al., 2015: Distribution and mixing of old and new nonstructural carbon in two temperate trees. New Phytologist, 206:590-597.

San-Miguel-Ayanz, J., de Rigo, D., Caudullo, G., Durrant, T.H. et al., 2016: European Atlas of Forest Tree Species. Luxembourg, Publication Office of European Union, $200 \mathrm{p}$.

Schua, K., Wende, S., Wagner, S., Feger, K.-H., 2015: Soil chemical and microbial properties in a mixed stand of spruce and birch in the Ore Mountains (Germany) - A case study. Forests, 6:1949-1965.

Sebastia, M.-T., 2007: Plant guilds drive biomass response to global warming and water availability in subalpine grassland. Journal of Applied Ecology, 44:158-167.

Seidl, R., Schelhaas, M.-J., Rammer, W., Verkerk, P.J., 2014: Increasing forest disturbances in Europe and their impact on carbon storage. Nature Climate Change, 4:806-810.

Sharma, R.P., Vacek, Z., Vacek, S., 2016: Modeling individual tree height to diameter ratio for Norway spruce and European beech in Czech Republic. Trees, 30:1969-1982.

Shipley, B., 2006: Net assimilation rate, specific leaf area and leaf mass ratio: which is most closely correlated with relative growth rate? A meta-analysis. Functional Ecology, 20:565-574.
Snowdon, P., Waring, H. D., Woollons, R. C., 1981: Effect of fertilizer and weed control on stem form and average taper in plantation-grown pines. Australian Forestry Journal, 11:209-221.

Song, M., Hu, Q., Tian, Y., Ouyang, H., 2012: Seasonal patterns of root and shoot interactions in an alpine meadow on the Tibetan Plateau. Journal of Plant Ecology 5:182-190.

Stark, H., Nothdurft, A., Bauhus, J., 2013: Allometries for widely spaced Populus ssp. and Betula ssp. in nurse crop systems. Forests, 4:1003-1031.

Šebeň, V., 2017: Národná inventarizácia a monitoring lesov Slovenskej republiky 2015-2016. Lesnícke štúdie 65, Zvolen, National Forest Centre, 255 p.

Uri, V., Lohmus, K., Ostonen, I., Tullus, H., Lastik, R., Vildo, M., 2007: Biomass production, foliar and root characteristics and nutrient accumulation in young silver birch (Betula pendula Roth.) stand growing on abandoned agricultural land. European Journal of Forest Research, 126:495-506.

Valkonen, S., Valsta, L., 2001: Productivity and economics of mixed two-storied spruce and birch stands in Southern Finland simulated with empirical models. Forest Ecology and Management, 140:133-149.

Vološčuk, I. et al., 1994: Tatra National Park. Martin, Slovakia: Gradus, Ltd., 557 p.

Wang, Y., Titus, S. J., LeMay, V. M., 1998: Relationship between tree slenderness coefficient and tree or stand characteristics for major species in boreal mixed wood forests. Canadian Journal of Forest Research, 28:1171-1183.

Wang, J., Zhang, C., Xia, F., Zhao, X., Wu, L., von Gadow, K., 2011: Biomass Structure and Allometry of Abies nephrolepis (Maxim) in Northeast China. Silva Fennica, 45:211-226.

Wiklund, K., Konôpka, B., Nilsson, L.-O., 1995: Stem form and growth in Picea abies (L.) Karst. In response to water and mineral nutrient availability. Scandinavian Journal of Forest Research, 10:326-332.

Yang, X.-Z., Zhang, W. H., He, Q. Y., 2019: Effects of intraspecific competition on growth, architecture and biomass allocation of Quercus liaotungensis. Journal of Plant Interactions, 14:284-294.

Zasada, M., Bijak, S., Bronisz, K., Bronisz, A., Gaweda, T., 2014: Biomass dynamics in young silver birch stands on post-agricultural lands in central Poland. Drewno, 57:29-39.

Zhou, W., Cheng, X., Wu, R., Han, H., Kang, F., Zhu, J. et al., 2018: Effect of intraspecific competition on biomass partitioning of Larix principis-rupprechtii. Journal of Plant Interactions, 13:1-8. 